\title{
PENGARUH KOMPENSASI, KOMPETENSI DAN KOMITMEN ORGANISASIONAL TERHADAP KEPUASAN DAN KINERJA
}

\author{
Yudi Supiyanto \\ Universitas PGRI Ronggolawe Tuban, Indonesia \\ Email: supiyantoyudi@yahoo.co.id
}

\begin{abstract}
Abstrak: Pengaruh Kompensasi, Kompetensi dan Komitmen Organisasional Terhadap Kepuasan dan Kinerja. Penelitian ini bertujuan menguji pengaruh kompensasi, kompetensi dan komitmen organisasional terhadap kepuasan kerja dan kinerja karyawan koperasi. Populasi dalam penelitian ini adalah seluruh karyawan KSP (Koperasi Simpan Pinjam) yang tersebar di Kabupaten Tuban. Analisis data menggunakan teknik Path Analysis dengan model trimming. Temuan penelitian menunjukkan bahwa kompensasi, kompetensi dan komitmen organisasi baik secara simultan maupun parsial berpengaruh signifikan terhadap kepuasan kerja karyawan. Kompensasi, kompetensi, komitmen organisasi dan kepuasan kerja secara simultan berpengaruh signifikan terhadap kinerja karyawan; namun secara parsial kompetensi dan kepuasan kerja tidak berpengaruh terhadap kinerja karyawan.
\end{abstract}

Kata kunci: Kompensasi, Kompetensi, Komitmen Organisasional, Kepuasan Kerja Dan Kinerja Karyawan.

\begin{abstract}
The Effect of Compensation, Competencies and Organizational Commitment toward Job Satisfaction and Performance. The purpose of this study is to examine the effect of compensation, competencies and organizational commitment to employee's job satisfaction and performance of cooperatives. The population in this study is all employees of KSP (Credit Unions/Loan and Saving Cooperative) in Tuban. Data analysis employed is path analysis with trimming model. The study's findings indicate that the compensation, competency and organizational commitment simultaneously and partially have a significant effect on employee's job satisfaction. Compensation, competencies, organizational commitment and job satisfaction simultaneously have a significant effect on employee's performance, but partially competence and job satisfaction do not has a significant effect on employee's performance.
\end{abstract}

Keywords: compensation, competency, organizational comitment, job satisfaction, employee's performance

\section{PENDAHULUAN.}

Koperasi idealisnya menjadi soko guru ekonomi nasional sebagaimana sering disebutkan maka diharapkan koperasi menjadi kekuatan ekonomi yang utama dan melebihi kekuatan dari pada dua pelaku ekonomi lainnya. Hal ini tercermin di dalam peran koperasi dimana koperasi selain sebagai alat untuk mempertinggi kualitas kehidupan manusia dan masyarakat juga merupakan alat untuk memperkokoh perekonomian rakyat sebagai dasar kekuatan dan ketahanan perekonomian nasional (Rintuh, 1995). Namun dalam kenyataaannya koperasi justru berada pada level paling bawah terutama jika dilihat dari berapa besar sumbangan koperasi terhadap Pendapatan Nasional dibandingkan dengan 
sektor ekonomi lainnya (http://studensite. gunadarma.ac.id).

Rendahnya kinerja koperasi seperti yang diuraikan di atas tidaklah terlepas dari peran SDM (sumber daya manusianya) yakni karyawan di mana mereka bekerja dan memberikan seluruh kemampuannya guna mencapai kinerja yang diharapkan. Peran sumber daya manusia dari waktu ke waktu semakin mendapat tempat yang strategis dalam aktivitas bisnis koperasi. Beberapa ahli SDM mengajukan peran-peran tersebut sebagai peran baru SDM (Schuler \& Jackson, 1987) yang terkait dengan strategi organisasi. Perspektif resource-based view berpandangan bahwa kapabilitas sumberdaya manusia adalah sumberdaya potensial untuk sustainable competitive advantage bagi organisasi. Hal tersebut digambarkan sebagai kapabilitas SDM yang dapat membantu perusahaan memperoleh keunggulan kompetitif dengan praktikpraktik manajemen sumber daya manusia dan mendorong fokus pada pelanggan (Schuler dan Jackson, 1994). Untuk itulah Ulrich ( 1997) menyarankan 4 peran baru yang harus dimainkan oleh Fungsi SDM dan para praktisinya, agar dapat memberikan hasil dan menciptakan keuntungan dari keberadaan mereka di dalam perusahaan, yaitu :1). Mitra bisnis strategis sebagai mitra bisnis strategis, Fungsi SDM dan para praktisinya dituntut untuk mempunyai kemampuan dalam menterjemahkan strategi bisnis yang ditetapkan perusahaan, menjadi tindakan-tindakan yang nyata di lapangan, 2) Ahli di bidang administrasi, sebagai ahli di bidang administrasi, Fungsi SDM dan para praktisinya harus mampu melakukan rekayasa ulang terhadap proses- proses kerja yang dilakukannya selama ini, 3). Pendukung dan pendorong kemajuan karyawan, dalam perannya sebagai pendukung dan pendorong kemajuan karyawan, 4). Agen perubahan, dalam kapasitasnya sebagai agen perubahan, Fungsi SDM dan para praktisinya dituntut untuk mampu menjadi katalisator perubahan di dalam perusahaan. Fungsi SDM dan para praktisinya harus mampu berperan dalam mempercepat dan mengelola proses perubahan yang dicanangkan oleh perusahaan secara efektif. Di samping itu, mereka dituntut pula untuk mampu mengenali hambatan-hambatan yang mungkin dihadapi oleh perusahaan bila perubahan dilakukan. Dengan demikian dapat mencegah terjadinya gejolak sosial, yang kontra produktif di dalam perusahaan dan tentu saja tampilan kinerja SDM yang diharapkan terus meningkat dalam jangka panjang meskipun dalam perjalanannya mengalami permasalahan penurunan kinerja.

Masalah penurunan kinerja dari SDM karyawan telah banyak diteliti oleh para peneliti bukan saja dikaitkan dengan faktor kompetensi namun juga beberapa faktor atau variabel manajemen sumber daya manusia dan perilaku organisasi serta motivasi Keith Davis dan McCleland dalam Mangkunegara, 2011). Selain itu masalah pengelolaan sumber daya manusia (SDM) di koperasi khususnya menyangkut profesionalisme dan moral personel koperasi begitu juga masalah pemanfaatan teknologi (Dinas KUMKM Jatim, 2013). Dalam penelitian ini beberapa factor manajemen sumber daya manusia dan perilaku organisasi yang diduga 
mempengaruhi kinerja karyawan adalah kompensasi, kompetensi, komitmen organisasional, dan kepuasan kerja.

Kompensasi merupakan suatu yang diterima karyawan sebagai pengganti kontribusi jasa mereka kepada organisasi Rivai (2005). Untuk menyusun sistem pemberian kompensasi yang adil, manajemen perlu melakukan "evaluasi pekerjaan". Dengan evaluasi, manajemen berupaya mempertimbangkan dan mengukur masukan karyawan (ketrampilan, usaha, tanggung jawab dan sebagainya) untuk menetapkan kinerja minimum dan merubah ukuran dalam satuan uang. Kompensasi juga merupakan pendorong utama karyawan untuk bekerja, karena dengan kompensasi berupa Financial para karyawan dapat memenuhi kebutuhannya. Sehingga kompensasi berpengaruh terhadap kinerja karyawan. Kompensasi dipandang sebagai salah satu factor SDM yang berpengaruh terhadap kinerja karyawan. Hal ini diperkuat oleh Rivai (2011) bahwa kompensasi antara lain untuk menghargai kinerja karyawan. Sutrisno (2011) mengatakan bahwa ada semacam imbal balik harapan antara perusahaan pemberi kompensasi dengan karyawan yang menerimanya yakni tujuan seorang pekerja bekerja adalah untuk memperoleh kompensasi dan pihak perusahaan mengharapkan karyawan memberikan kinerja yang terbaik bagi organisasinya.

Kompetensi terkait dengan peran SDM dalam organisasi atau perusahaan mempunyai arti yang sama pentingnya dengan pekerjaan itu sendiri, mengingat pentingnya peran Sumber Daya Manusia dalam organisasi atau koperasi dalam hal ini,
SDM sebagai faktor penentu organisasi atau perusahaan maka kompetensi menjadi aspek yang menentukan keberhasilan organisasi atau perusahaan. Dengan Kompetensi yang tinggi yang dimiliki oleh SDM dalam suatu organisasi atau perusahaan tentu hal ini akan menentukan kualitas SDM yang dimiliki yang pada akhirnya akan menentukan kualitas kompetitif perusahaan itu sendiri. Konsep kompetensi sebenarnya bukan sesuatu yang baru. Menurut Organisasi Industri Psikologi Amerika (Mitrani, Palziel and Fitt, 1992: 14) gerakan kompetensi telah dimulai pada tahun 1960 dan awal 1970. Apakah yang dimaksud dengan Kompetensi? Menurut Spencer and Spencer, (1993 : 9) Kompetensi adalah sebagai karakteristikyang mendasari seseorang dan berkaitan dengan efektifitas kinerja individu dalam pekerjaannya (an underlying characteristic's of an individual which is causally related to criterion referenced effective and or superior performance in a job or situation). Ruky (2003) selanjutnya mengatakan bahwa kompetensi dibutuhkan untuk melaksanakan peran tertentu untuk menghasilkan kinerja berupa prestasi kerja yang memuaskan. Hasil penelitian Mc. Clelland (dalam Umara, 2002) menunjukkan bahwa kompetensi berhasil memprediksi kinerja atau prestasi kerja individu dalam pekerjaan.

Komitmen organisasional menurut Meyer dkk (1997) tidak hanya berhubungan dengan tingkat keluar masuknya karyawan, melainkan juga berkaitan dengan tingkat kerelaan karyawan untuk berkorban bagi perusahaan. Komitmen organisasional menurut Allen dan Meyer (dalam Dunham 
dkk, 1994) dapat diartikan sebagai kelekatan emosi, identifikasi dan keterlibatan individu dengan organisasi serta keinginan untuk tetap menjadi anggota organisasi.. Sistem tanggapan yang disediakan oleh organisasi terkadang kurang mendapat perhatian dari para karyawan untuk lebih menumbuhkan sikap loyal terhadap karyawan, hal ini disebabkan adanya rasa khawatir dari para karyawan akan mendapatkan sanksi bila menyampaikan keluhannya. Oleh karena itu perlunya kepercayaan yang tinggi serta dukungan organisasi terhadap karyawan menjadi suatu hal yang penting bagi tiap-tiap anggota organisasi (Buchanan dan Boswell, 2002). Steers (dalam Oktorita, Rossyid, Lestari, 2001) menyebutkan bahwa komitmen yang kuat dapat membawa dampak positif, antara lain: peningkatan prestasi kerja, motivasi kerja, masa kerja, produktivitas kerja, dan karyawan lebih rajin masuk kerja sehingga mengurangi absensi dan menurunkan turn over.

Kepuasan kerja karyawan menurut Robbins (dalam Wibowo, 2007:323) didefinisikan sebagai sikap umum terhadap pekerjaan seseorang yang menunjukkan perbedaan antara jumlah penghargaan yang diterima pekerja dan jumlah yang mereka yakini seharusnya mereka terima. Demikian juga pernyataan Vroom mengandung petunjuk mengapa kepuasan kerja dan kinerja saling berkaitan meskipun kenyataan bahwa keduanya disebabkan oleh hal yang berbeda (Lawler, 2003). Dalam beberapa penelitian terdapat banyak fakta bahwa kepuasan kerja berpangaruh pada kinerja personel dan kinerja koperasi. Bahkan Robbins (2007) menyatakan bahwa hubungan antara keduanya lebih tepat disebut "mitos manajemen" dan sulit untuk menetapkan ke arah mana hubungan sebab akibat di antara keduanya. Namun dari berbagai penelitian ditemukan pula bukti bahwa organisasi yang memiliki karyawan yang lebih puas cenderung lebih efektif dibandingkan organisasi yang memiliki karyawan yang kurang puas. Penelitian Latif Dkk (2013) memperkuat bagaimana peran kepuasan kerja terhadap kinerja organisasi di mana dalam penelitian keduanya memiliki pengaruh yang positif signifikan. Gibson, et.al (1995) menjelaskan bahwa kinerja organisasi tergantung pada kinerja pegawainya, atau dengan kata lain kinerja pegawai akan memberikan kontribusi pada kinerja organisasi. Apa yang dikemukakan Gibson tersebut dapat diartikan bahwa perilaku anggota organisasi baik secara individu ataupun kelompok dapat memberikan kekuatan atau pengaruh atas kinerja organisasinya.

Kinerja menurut Mathis dan Jackson (2002) mendefinisikan bahwa kinerja sebagai apa yang dilakukan dan tidak dilakukan personel yang mempengaruhi seberapa banyak mereka memberi kontribusi kepada organisasi yang antara lain meliputi kuantitas output, kualitas output, jangka waktu output, kehadiran di tempat kerja dan sikap kooperatif. Kinerja karyawan dalam penelitian ini dipandang memiliki pengaruh yang kuat terhadap keberhasilan kerja. Dalam penelitian Rusdarti (2009) ditemukan bahwa kemampuan kinerja karyawan adalah aspek kemampuan yang sangat menentukan keberhasilan kerja. Pada gilirannya dari hasil kerja yang efektif, karyawan akan dapat mendapat penghargaan dari para anggotanya yang 
berupa kepercayaan. Pendapat ini jelas bagaimana kontribusi kinerja personel terhadap kinerja organisasi. Pada gilirannya dari hasil kinerja yang efektif, SDM karyawannya maka KSP akan dapat mendapat penghargaan dari para anggotanya yang berupa kepercayaan.

Penelitian ini mengambil objek di KSP (Koperasi Simpan Pinjam) wilayah Tuban. Adapun rumusan masalah dalam penelitian ini sebagai berikut: 1). Adakah pengaruh signifikan Kompensasi, Kompetensi, dan Komitmen Organisasi secara simultan terhadap Kepuasan Kerja karyawan KSP di Tuban? 2). Adakah pengaruh signifikan Kompensasi terhadap Kepuasan Kerja karyawan KSP di Tuban?.3). Adakah pengaruh signifikan Kompetensi terhadap Kepuasan Kerja karyawan KSP di Tuban? 4), Adakah pengaruh signifikan Komitmen Organisasional terhadap Kepuasan Kerja karyawan KSP di Tuban? 5). Adakah pengaruh signifikan Kompensasi, Kompetensi, Komitmen Organisasi, dan Kepuasan Kerja secara simultan terhadap Kinerja Karyawan KSP di Tuban? 6) Adakah pengaruh signifikan Kompensasi terhadap Kinerja Karyawan KSP di Tuban? 7) Adakah pengaruh. signifikan Kompetensi terhadap Kinerja Karyawan KSP di Tuban? 8). Adakah pengaruh signifikan Komitmen Organisasional terhadap Kinerja Karyawan KSP di Tuban? 9). Adakah pengaruh signifikan Kepuasan Kerja terhadap Kinerja Karyawan KSP di Tuban?

\section{METODE}

Penelitian ini tujuannya adalah untuk mengkaji pengaruh kompensasi (X1), Kompetensi (X2), Komitmen organisasional
(X3), dan Kepuasan kerja (X4) dan variabel terikat (dependent variabel) Y satu variabel yakni: Kinerja Karyawan (Y). Oleh karena itu maka pendekatan yang digunakan adalah pendekatan kuantitatif dengan desain atau rancangan korelasional. Hal ini seperti yang dikatakan oleh More (1983) dan Arikunto (1995) bahwa penelitian korelasional tidak saja menunjukkan antar hubungan, di samping itu dapat juga menyatakan hubungan kausal. Kuncoro (2009) mengatakan bahwa penelitian korelasional berusaha untuk menentukan apakah terdapat hubungan (asosiasi) antara dua variable atau lebih serta seberapa jauh korelasi yang ada antara variabel yang diteliti. Inti dari analisis korelasi adalah mengukur kekuatan hubungan namun juga jika ada hubungan yang kuat di antara variable maka dengan analisis selanjutnya bisa diketahui hubungan sebab akibat yang ada. Sedangkan kerangka konseptual penelitian dapat dilihat pada Gambar 1.

Berdasarkan pada latar belakang masalah, perumusan masalah, dan tinjauan pustaka serta kerangka konseptual yang telah dirumuskan maka hipotesis yang diajukan dalam penelitian ini adalah:

1. Kompensasi, Kompetensi SDM, dan Komitmen Organisasi secara simultan berpengaruh signifikan terhadap Kepuasan Kerja karyawan KSP di Tuban.

2. Kompensasi berpengaruh signifikan terhadap Kepuasan Kerja karyawan KSP di Tuban.

3. Kompetensi SDM berpengaruh signifikan terhadap Kepuasan Kerja karyawan KSP di Tuban. 


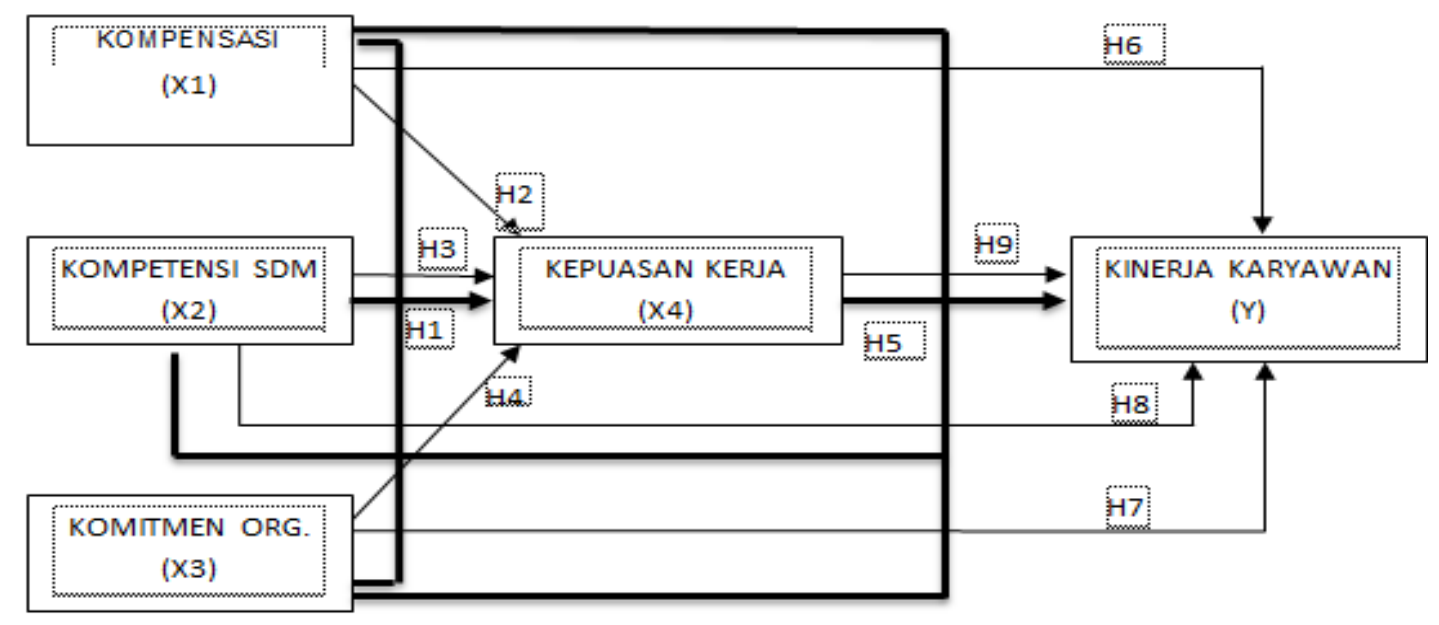

Gambar 1. Kerangka Konseptual Penelitian

4. Komitmen Organisasional berpengaruh signifikan terhadap Kepuasan Kerja karyawan KSP di Tuban.

5. Kompensasi, Kompetensi SDM, Komitmen Organisasi, dan Kepuasan Kerja secara simultan berpengaruh signifikan terhadap Kinerja Karyawan KSP di Tuban.

6. Kompensasi berpengaruh signifikan terhadap Kinerja Karyawan KSP di Tuban.

7. Kompetensi SDM berpengaruh signifikan terhadap Kinerja Karyawan KSP di Tuban.

8. Komitmen Organisasional berpengaruh signifikan terhadap Kinerja Karyawan KSP di Tuban.

9. Kepuasan Kerja berpengaruh signifikan terhadap Kinerja Karyawan KSP di Tuban. Jumlah populasi dalam penelitian ini adalah sebanyak 159 orang karyawan KSP yang tersebar di beberapa kecamatan di Kabupaten Tuban. Adapun teknik sampling yang akan digunakan adalah gabungan teknik Area sampling dan Random sampling sederhana. Area sampling adalah teknik sampling yang digunakan jika data atau populasi sangat luas misalnya penduduk atau karyawan perusahaan yang tersebar di seluruh propinsi, atau kabupaten (Sugiono, 2007; Arikunto, 2010). Berdasarkan kombinasi teknik sampling di atas maka akan didapat sampel sebesar 108 karyawan KSP. Teknik Pengambilan Data.Tehnik pengambilan data adalah dengan menggunakan angket atau Kuisioner. Angket digunakan untuk mengumpulkan data keseluruhan dari variabel penelitian ini. Kemudian skala jawaban yang digunakan dalam angket adalah menggunakan Skala Likert. Skala Likert mengukur sikap pendapat dan persepsi seseorang atau sekelompok orang tentang fenomena sosial (Sekaran, 2000; Suprapto, 2004, Sugiono, 2009). Dalam skala Likert menggunakan angka 1 sampai 5 di mana angka 1 menunjukkan skor terendah sedang angka 5 menunjukkan skor tertinggi. Adapun kuesioner dikembangkan menggunakan indikator kompensasi yang dikembangkan Simamora (2004:443) yakni langsung dan tidak langsung, indikator kompetensi SDM menurut Susilo $d k k$ (2007:17). yakni: 1) Fisik, 2) Emosi dan 3) Spiritual, indikator dari komitmen organisasional Meyer dan Allen (1997) yakni Komitmen afektif, Komitmen kontinuitas 
:dan Komitmen normative, indikator Smith dkk untuk mengukur kepuasan kerja karyawan koperasi yaitu : 1). Pekerjaan itu sendiri, 2). gaji, 3). kesempatan promosi, 4), penyelia dan 5), rekan kerja. Dan indikator kinerja menurut pendapat Bernadin (1998) yakni: Kualitas, Kuantitas, Ketepatan Waktu, Efektivitas, dan Kemandirian. Selanjutnya untuk menguji hipotesis yang telah dirumuskan dalam penelitian ini maka metode analisis data inferensialnya adalah menggunakan analisis jalur atau path analysis. Analisis Jalur atau Path Analysis adalah dilakukan dengan analisis regresi ganda secara terstandar atau bertahap (Sundjoto dkk, 2014; Hasan, 1996; Kerlinger 1986; Joreskog dan Sorbom, 1996; Johnson dan Wichern, 1992).

\section{HASIL DAN PEMBAHASAN.}

Untuk melihat besaran pengaruh secara simultan kompensasi, kompetensi SDM dan komitmen organisasi terhadap kepuasan kerja dapat dilihat dari perhitungan tabel summary dan ANOVA pada hasil hitung SPSS. Kaidah pengujian signifikansi adalah jika nilai probabilitas 0.05 lebih kecil atau sama dengan nilai probabilitas sig atau ( $0.05 \leq \mathrm{sig})$, maka Ho diterima dan Ha ditolak, artinya tidak signifikan, sedangkan jika nilai probabilitas 0.05 lebih besar atau sama dengan nilai probabilitas sig atau (0.05 $\geq \mathrm{sig}$ ), maka Ha diterima dan Ho ditolak, artinya signifikan.

Hipotesisnya sebagai berikut:

Ho1 = Tidak ada pengaruh yang signifikan secara bersama antara kompensasi, kompetensi SDM dan komitmen organisasi terhadap kepuasan kerja
Ha1 = Ada pengaruh yang signifikan secara bersama antara kompensasi, kompetensi SDM dan komitmen organisasi terhadap kepuasan kerja

Tabel model summary diperoleh nilai $R$ square $=0.914$, selanjutnya tabel ANOVA diperoleh nilai $F$ sebesar 349.417 dengan nilai probabilitas (sig) sebesar 0.000. Karena nilai sig $\leq$ dari 0.05 maka Ha1 diterima dan Ho1 ditolak. Dari hasil perhitungan signifikansi tabel $\mathrm{F}$ menunjukkan bahwa ada pengaruh antara kompensasi, kompetensi SDM dan komitmen organisasi terhadap kepuasan kerja, hasil yang diperoleh di nilai $\mathrm{R}$ square dapat dikatakan bahwa besaran pengaruh kompensasi, kompetensi SDM dan komitmen organisasi terhadap kepuasan kerja adalah sebesar 0.914 atau 91.40\%, sisanya $\mathrm{px}_{4} € 1$ atau variabel lain di luar variabel kecerdasan emosional dan kecerdasan spiritual adalah sebesar 1-0.914 $=0.086$ atau $8.60 \%$ dihitung dengan rumus 1 $-R^{2} \times 4 \times 1 \times 2 \times 3$. Hasil penelitian ini sesuai dengan temuan empiric dari Mardahleni (2013) yang menyatakan bahwa kompensasi berpengaruh positif terhadap kepuasan kerja, Windra Mei (2014) bahwa komitmen berpengaruh signifikan terhadap kepuasan kerja, \%. Hasil penelitian ini relevan dengan hasil penelitian Akhmadi, Nanang Tia (2009) yang menyatakan bahwa komitmen berpengaruh signifikan terhadap kepuasan kerja karyawan. Hasil penelitian ini relevan dengan hasil penelitian Wardani, Kusuma (2007) di mana hasil penelitian menunjukkan bahwa kompetensi berpengaruh terhadap kepuasan kerja karyawan dengan kontribusi sebesar 56,7\%, sedangkan 43,3\% dipengaruhi oleh faktor lain. 
Pengaruh Kompensasi terhadap Kepuasan Kerja

Hipotesisnya adalah sebagai berikut:

$\mathrm{Ho} 2$ = Tidak ada pengaruh yang signifikan antara kompensasi terhadap kepuasan kerja $\mathrm{Ha} 2$ = Ada pengaruh yang signifikan antara kompensasi terhadap kepuasan kerja

Dari hasil analisis diperoleh nilai beta untuk variabel kompensasi sebesar 0.380 dan besaran $t_{\text {hitung }}$ sebesar 7.850 dengan besaran sig sebesar 0.000 , karena sig $\leq$ dari 0.05 maka Ha2 diterima dan Ho2 ditolak. Dari hasil perhitungan tersebut dapat disimpulkan bahwa kompensasi berpengaruh terhadap kepuasan kerja dibuktikan dengan nilai thitung sebesar 7.850 yang signifikan dan besaran pengaruh yang diberikan terlihat dari kolom beta adalah sebesar 0.380 atau $38.00 \%$. Hasil penelitian ini relevan dengan temuan penelitian Mardahleni (2013) yang menemukan bahwa kompensasi berpengaruh signifikan terhadap kepuasan kerja. Juga hasil penelitian Pebriyanti dkk (2011) di mana kompensasi berpengaruh positif terhadap kepuasan kerja hal ini ditunjukkan dari signifikansi kompensasi terhadap kepuasan kerja karyawan 0,000 $<0,05$ atau nilai thitung $>$ t-tabel yaitu5,073 > 1,6634 dengan persentase pengaruhnya sebesar 23,7\%. Selain itu temuan penelitian ini relevan dengan teori Blum (dalam As'ad, 2001) bahwa terdapat beberapa faktor yang mempengaruhi kepuasan kerja yakni faktor individu, faktor sosial dan faktor utama dalam pekerjaan. Faktor utam dalam pekerjaan yang mempengaruhi kepuasa kerja karyawan di antaranya; gaji atau kompensasi, pengawasan, ketenteraman kerja, kondisi kerja dan kesempatan untuk maju. Selanjutnya Gilmer (1996) juga menyatakan bahwa salah satu yang mempengaruhi kepuasan kerja adalah kompensasi.

\section{Pengaruh Kompetensi SDM terhadap Kepuasan Kerja}

Hipotesisnya adalah sebagai berikut:

Ho3 = Tidak ada pengaruh yang signifikan antara kompetensi SDM terhadap kepuasan kerja

$\mathrm{Ha} 3=$ Ada pengaruh yang signifikan antara kompetensi SDM terhadap kepuasan kerja

Dari hasil analisis diperoleh nilai beta untuk variabel kompetensi SDM sebesar 0.214 dan besaran t hitung sebesar 3.871 dengan besaran sig sebesar 0.000 , karena sig < dari 0.05 maka Ha3 diterima dan Ho3 ditolak. Dari hasil perhitungan tersebut dapat disimpulkan bahwa kompetensi SDM berpengaruh terhadap kepuasan kerja dibuktikan dengan nilai $t_{\text {hitung }}$ sebesar 3.871 yang signifikan dan besaran pengaruh yang diberikan terlihat dari kolom beta adalah sebesar 0.214 atau $21.40 \%$. Hasil penelitian ini relevan dengan hasil penelitian Wardani dan Kusuma (2007) di mana hasil penelitian menunjukkan bahwa kompetensi berpengaruh terhadap kepuasan kerja karyawan dengan kontribusi sebesar $56,7 \%$, sedangkan 43,3\% dipengaruhi oleh faktor lain.

\section{Pengaruh Komitmen Organisasi terhadap}

\section{Kepuasan Kerja}

Hipotesisnya adalah sebagai berikut:

Ho4 = Tidak ada pengaruh yang signifikan antara komitmen organisasi terhadap kepuasan kerja 
$\mathrm{Ha} 4=$ Ada pengaruh yang signifikan antara komitmen organisasi terhadap kepuasan kerja

Dari hasil analisis diperoleh nilai beta untuk variabel komitmen organisasi sebesar 0.467 dan besaran t hitung sebesar 10.498 dengan besaran sig sebesar 0.000 , karena sig < dari 0.05 maka Ha4 diterima dan Ho4 ditolak. Dari hasil perhitungan tersebut dapat disimpulkan bahwa komitmen berpengaruh terhadap kepuasan kerja dibuktikan dengan nilai $t_{\text {hitung }}$ sebesar 10.498 yang signifikan dan besaran pengaruh yang diberikan terlihat dari kolom beta adalah sebesar 0.467 atau $46.70 \%$. Hasil penelitian ini relevan dengan hasil penelitian Akhmadi, Nanang Tia (2009) yang menyatakan bahwa komitmen berpengaruh signifikan terhadap kepuasan kerja karyawan.

\section{Menguji pengaruh kompensasi,} kompetensi SDM, komitmen organisasi dan kepuasan kerja terhadap kinerja karyawan secara simultan.

Hasil analisis juga ditemukan nilai $\mathrm{R}$ square $=$ 0.877, selanjutnya tabel ANOVA diperoleh nilai $F$ sebesar 175.016 dengan nilai probabilitas (sig) 0.000, karena nilai sig $\leq$ dari 0.05 maka Ha5 diterima dan Ho5 ditolak. Dari hasil perhitungan signifikansi tabel $F$ (table. 5.18) sebesar 175.016 menunjukkan bahwa ada pengaruh antara kompensasi, kompetensi SDM, komitmen organisasi dan kepuasan kerja terhadap kinerja karyawan, dan dari hasil yang diperoleh dinilai R square dapat dikatakan bahwa besaran pengaruh kompensasi, kompetensi SDM, komitmen organisasi dan kepuasan kerja secara bersama terhadap kinerja karyawan adalah sebesar 0.877 atau $87.70 \%$, sisanya py€2 atau variabel lain di luar variabel kompensasi, kompetensi SDM, komitmen organisasi dan kepuasan kerja adalah sebesar $1-0.877=0.123$ atau $12.30 \%$ dihitung dengan rumus $1-R^{2} \times 4 \times 1 \times 2 \times 3$. Hasil penelitian ini relevan dengan hasil temuan Haryanto, Mai (2012) yang menyatakan bahwa komitmen organisasi dan kepuasan kerja terhadap kinerja karyawan, Penelitian Wirda Aryuningrum menyatakan terdapat hubungan yang positif dan signifikan antara kompetensi sumber daya manusia dengan kinerja karyawan; Penelitian Akmal, dkk ( 2014) juga menyatakan kompensasi TPK berpengaruh terhadap kinerja pegawai Sekretariat Daerah Aceh. Kemudian Penelitian Hadiyatno (2012) menyatakan bahwa secara simultan variabel kompetensi, kompensasi, dam kepuasan kerja mempunyai pengaruh terhadap kinerja karyawan, secara parsial kompetensi mempunyai pengaruh terhadap kinerja, kompensasi mempunyai pengaruh terhadap kinerja karyawan dan kepuasan kerja mempunyai pengaruh terhadap kinerja

\section{Pengaruh Kompensasi terhadap Kinerja Karyawan}

Hipotesisnya adalah sebagai berikut:

Ho6 = Tidak ada pengaruh yang signifikan antara kompetensi terhadap kinerja karyawan

Ha6 = Ada pengaruh yang signifikan antara kompetensi terhadap kinerja karyawan

Dari hasil analisis diperoleh nilai beta untuk variabel kompensasi sebesar 0.367 dan besaran t hitung sebesar 4.957 dengan besaran sig sebesar 0.000 , karena sig $\leq$ dari 0.05, maka Ha6 diterima dan Ho6 ditolak. Dari hasil perhitungan tersebut dapat 
disimpulkan bahwa ada pengaruh yang signifikan antara kompensasi terhadap kinerja karyawan dibuktikan dengan nilai $t$ hitung sebesar 4.957 yang signifikan dan besaran pengaruh yang diberikan terlihat dari kolom beta adalah sebesar 0.367 atau $36.70 \%$. Hasil penelitian ini relevan dengan Penelitian Akmal, dkk( 2014) menyatakan bahwa menunjukkan kompensasi TPK berpengaruh terhadap kinerja pegawai Sekretariat Daerah Aceh.

\section{Pengaruh Kompetensi SDM terhadap}

\section{Kinerja Karyawan}

Hipotesisnya adalah sebagai berikut:

$\mathrm{Ho7}=$ Tidak ada pengaruh yang signifikan antara kompetensi SDM terhadap kinerja karyawan

$\mathrm{Ha} 7=$ Ada pengaruh yang signifikan antara kompetensi SDM terhadap kinerja karyawan

Dari hasil analisis diperoleh nilai beta untuk variabel kompetensi SDM adalah 0.073 dengan t hitung sebesar -1.023 dan sig sebesar 0.309 , karena nilai sig $\geq$ dari 0.05 maka Ho7 diterima dan $\mathrm{Ha} 7$ ditolak. Dari hasil tersebut dapat disimpulkan bahwa tidak ada pengaruh yang signifikan antara kompetensi SDM terhadap kinerja karyawan, Hasil penelitian ini tidak relevan dengan penelitian Wirda Aryuningrum yang menyatakan bahwa terdapat hubungan yang positif dan signifikan antara kompetensi sumber daya manusia dengan kinerja karyawan. Namun hasil penelitian ini relevan dengan hasil temuan penelitian Dhermawan dkk (2012) yang menyatakan bahwa kompetensi berpengaruh tidak signifikan terhadap kinerja pegawai sementara lingkungan kerja.

\section{Pengaruh Komitmen Organisasi terhadap}

\section{Kinerja Karyawan}

Hipotesisnya adalah sebagai berikut:

$\mathrm{Ho8}=$ Tidak ada pengaruh yang signifikan antara komitmen organisasi terhadap kinerja karyawan

$\mathrm{Ha} 8=$ Ada pengaruh yang signifikan antara komitmen organisasi terhadap kinerja karyawan

Dari hasil analisis diperoleh nilai beta untuk variabel komitmen organisasi sebesar 0.496 dan besaran $t$ hitung sebesar 6.390 dengan besaran sig sebesar 0.000 , karena sig $\leq$ dari 0.05, maka Ha8 diterima dan Ho8 ditolak. Dari hasil perhitungan tersebut dapat disimpulkan bahwa ada pengaruh yang signifikan antara komitmen organisasi terhadap kinerja karyawan dibuktikan dengan nilai t hitung sebesar 6.390 yang signifikan dan besaran pengaruh yang diberikan terlihat dari kolom beta adalah sebesar 0.496 atau $49.60 \%$. Hasil penelitian ini relevan dengan hasil penelitian Haryanto, Mai (2012) yang menyatakan bahwa ada pengaruh yang signifikan antara komitmen organisasi dengan kinerja karyawan. Kemudian Penelitian Sugiono (2009), menyatakan juga bahwa secara langsung atau tidak langsung komitmen berpengaruh positif signifikan terhadap Kinerja Tugas. Diperkuat juga oleh penelitian Verawati dan Utomo (2011) yang menyatakan bahwa secara simultan organization commitment, participation and motivation are influence on work performance.

\section{Pengaruh Kepuasan Kerja terhadap Kinerja}

\section{Karyawan}

Hipotesisnya adalah sebagai berikut: 
Ho9 = Tidak ada pengaruh yang signifikan antara kepuasan kerja terhadap kinerja karyawan

$\mathrm{Ha}$ = Ada pengaruh yang signifikan antara kepuasan kerja terhadap kinerja karyawan

Dari hasil analisis diperoleh nilai beta untuk variabel kepuasan kerja adalah 0.224 dengan $t$ hitung sebesar 1.855 dan sig sebesar 0.067 , karena nilai sig $\geq$ dari 0.05 maka Ho9 diterima dan Ha9 ditolak. Dari hasil tersebut dapat disimpulkan bahwa ada pengaruh namun tidak signifikan antara kepuasan kerja terhadap kinerja karyawan. Hasil penelitian ini tidak relevan dengan hasil temuan Penelitian Haryanto,. Penelitian ini juga tidak relevan dengan hasil Engko (2006) this study are the positive effect of job satisfaction and self esteem, job satisfaction and self efficacy, job satisfaction and job performance, self esteem and self efficacy, Penelitian ini relevan dengan penelitian Ostrof pada tahun 1992 dan meta analisis yang dilakukan Iffaldano dan Mochinsky pada tahun 1986 menemukan bukti empiris bahwa hubungan kepuasan kerja dengan kinerja tidak signifikan (dalam Engko, 2008; Ostroff, C. (1992).

\section{Pengujian koefisien model: koefisien Q}

Uji kesesuaian model menguji apakah model yang diusulkan memiliki kesesuaian (fit) dengan data atau tidak. Hasil perhitungan menunjukkan bahwa nilai $\mathrm{W}$ hitung $\leq \mathrm{X}^{2}$ (2.022 $\leq 5.991)$. Hal ini menunjukkan bahwa matriks korelasi estimasi kedua model tidak berbeda (sama) dengan matriks korelasi sampel. Dapat diambil kesimpulan bahwa model empiris yang diperoleh dapat menggeneralisasikan tentang fenomena yang ada.

\section{SIMPULAN}

Berdasarkan hasil analisis dan pengujian hipotesis yang telah dilakukan, serta tujuan yang hendak dicapai dari penelitian, maka dapat diperoleh kesimpulan sebagai berikut:

1. Kompensasi, kompetensi SDM dan komitmen organisasi secara bersama sama berpengaruh positif signifikan terhadap kepuasan kerja karyawan KSP di kabupaten Tuban, sehingga apabila kompensasi, kompetensi SDM dan komitmen organisasi karyawan tinggi maka kinerja karyawan juga tinggi, sebaliknya akan terjadi jika ketiga variable rendah maka kinerja juga rendah,

2. Kompensasi berpengaruh positif signifikan terhadap kepuasan kerja karyawan KSP di kabupaten Tuban, sehingga apabila kompensasi tinggi maka kepuasan kerja karyawan juga tinggi dan sebaliknya jika kompensasi rendah maka kepuasan kerja juga rendah.

3. Kompetensi SDM berpengaruh positif signifikan terhadap kepuasan kerja karyawan KSP di kabupaten Tuban, sehingga apabila kompetensi SDM tinggi maka kepuasan kerja karyawan juga tinggi dan sebaliknya jika kompetensi SDM rendah maka kepuasan kerja karyawan juga rendah.

4. Komitmen organisasional berpengaruh positif signifikan terhadap kepuasan kerja karyawan KSP di kabupaten Tuba, sehingga apabila komitmen organisasi tinggi maka kepuasan kerja karyawan juga tinggi dan sebaliknya jika komitmen 
organisasi rendah maka kepuasan kerja rendah.

5. Kompensasi, kompetensi SDM, komitmen organisasi dan kepuasan kerja secara simultan berpengaruh positif signifikan terhadap kinerja karyawan KSP di kabupaten Tuban, sehingga jika kompensasi, kompetensi SDM, komitmen organisasi dan kepuasan kerja tinggi maka kinerja karyawan juga tinggi. Sebaliknya jika kompensasi, kompetensi SDM, komitmen organisasi dan kepuasan kerja rendah maka kinerja karyawan juga rendah.

6. Kompensasi berpengaruh positif signifikan terhadap kinerja karyawan KSP di kabupaten Tuban, sehingga jika kompensasi tinggi maka kinerja karyawan juga tinggi dan sebaliknya jika kompensasi rendah maka kinerja karyawan juga rendah.

7. Kompetensi SDM berpengaruh tidak signifikan terhadap kinerja karyawan KSP kabupaten Tuban, sehingga perubahan dalam kompetensi SDM tidak akan berdampak terhadap kinerja Karyawan.

8. Komitmen organisasi berpengaruh positif signifikan terhadap kinerja karyawan KSP kabupaten Tuban, sehingga jika komitmen organisasi tinggi maka kinerja karyawan juga tinggi dan sebaliknya jika komitmen organisasi rendah maka kinerja karyawan juga rendah.

9. Kepuasan kerja berpengaruh tidak signifikan terhadap kinerja karyawan KSP kabupaten Tuban, sehingga perubahan dalam kepuasan kerja tidak akan berdampak terhadap kinerja Karyawan.

\section{DAFTAR PUSTAKA}

Akmal, Zaldy. A.Rahman Lubis, Mukhlis Yunus. (2014) Pengaruh Kompensasi terhadap Motivasi dan Disiplin serta dampaknya pada Kinerja Pegawai Sekretariat Daerah Aceh. Laporan Penelitian. Aceh: Unsyiah. PPS.

As'ad, Mohamad. (2001) Kepemimpinan Efektif dalam Perusahaan, Suatu Pendekatan Psikologik, EdisiKedua, Yogyakarta: Liberty.

Ayuningrum, Wirda. (2012) Pengaruh Kompetensi Sumber Daya Manusia Terhadap Kinerja Karyawan di PT.PP. London Sumatra Tbk Medan. Laporan Penelitian.

Bernadin,H. John and Russel,Joice E.A (1999) Human Recourses Management, International Edition, Singapure, McGrawhill Inc.

Dhermawan, Anak Agung Ngurah Bagus, I Gde Adnyana Sudibya dan I Wayan Mudiartha Utama. (2012). Pengaruh Motivasi, Lingkungan Kerja, Kompetensi,Dan Kompensasi Terhadap Kepuasan Kerja Dan Kinerja Pegawai Di Lingkungan Kantor Dinas Pekerjaan Umum Provinsi Bali. Jurnal Manajemen, Strategi Bisnis, dan Kewirausahaan Vol. 6, 173 No. 2 Agustus 2012

Dunham, R. B., Grube, J. A. and Castaneda, M. B. (1994) Organizational Commitment. The Utility of an Integrative Definition, Journal of Applied Psychology, 79(3), 370-380.

Engko, Cecilia, (2006) Pengaruh Kepuasan Kerja Terhadap Kinerja Individual Dengan Self Esteem Dan Self Efficacy Sebagai Variabel Intervening. Jurnal bisnis dan akuntansi, 10(1), 1-12. 
Gibson, Ivancevich dan Donelly. (1995) Organisasi, Perilaku, Struktur, Proses. Jakarta: Binarupa Aksara.

Gilbert, Thomas F (1996) Human Competence, HRD Amherst, Massachusetts. Journal of Behavioral Studies in Business Organizational Citizenship, Page 1.

Hannel (1989) Organisasi Koperasi. Bandung: Universitas Padjajaran.

Haryanto, Windra Mai (2012) Analisis pengaruh motivasi, komitmen organisasi dan kepuasan kerja terhadap kinerja karyawan (studi kasus PT Bank DKI). Masters thesis, Institut Pertanian Bogor.

Hasibuan, Malayu. SP. (2005) Manajemen Sumber Daya manusia. Edisi Revisi. Jakarta: Pt. Bumi Aksara

I Wayan Bagja. (2005) Pengaruh Modal Intelektual dan Kepuasan Kerja Terhadap Kinerja Pegawai

Kementerian Koperasi dan Usaha Kecil dan Menengah RepublikIndonesia (Kemenkop UKM). Tanpa Tahun Rekapitulasi Data Koperasi Berdasarkan Propinsi 2000 s.d. 2010. (Online), (http://www.depkop.go.id). Diakses tgl. 11 Pebruari 2014.

Kuncoro, Mudrajad. (2009) Metode Riset Untuk Bisnis dan Ekonomi. Jakarta: Erlangga.

Latif, Muhammad Shahzad Mushtaq Ahmad, Muhammad Qasim. (2013) Impact of employee's job satisfaction on organizational performance. European Journal of Business and Management www.iiste.org ISSN 2222-1905 (Paper) ISSN 2222-2839 (Online) 5(5).

Lawler III, (1998) Job Satisfaction and Expression Of Emotion in Organizations. Boston: McGraw-Hill Companies, Inc.

Lyle M. Spencer, Jr. Phc. and Signe M. Spencer (1993) Competence At Work
Models For Superior Performance. Boston: John Wiley \& Sons,Inc.

Mangkuprawira. A.P.( 2007). Evaluasia Kinerja Sumber Daya Manusia. Bandung: PT. Refika Avitama.

Mathis, R.L., \& Jackson, J.H. (2000). Human resource management. Australia: SouthWestern: College Publishing.

Meyer, J. P. Allen, N. J. Smith, C. A. (1993) Commitment to Organizations and Occupations: Extensionand Test of a Three-Component Conceptualization. Journal of Applied Psychology, 78, 538552.

Meyer, J.P.,\& Allen, N.J. (1997) Commitment in the workplace. Thousand Oaks, CA: Sage.

Mudrajad, Kuncoro (2009) Metode Riset Untuk Bisnis dan Ekonomi, Bagaimana Meneliti dan Menulis Tesis? Edisi 3. Jogyakarta: Erlangga.

Rintuh, Cornelis. (1995) Perekonomian Indonesia. Yogyakarta: Liberty Offset.

Rivai, Vetsal. (2011) Manajemen Sumber Daya manusia Untuk Perusahaan. Jakarta: PT. Rajagrafindo Persada.

Robbins, S. P. (1993) Organizational Behavior: Concept, Controversies and Applications. Sixth Edition.New Jersey : Prentice Hall International, Inc

Robbins, Stephen. (2007) Perilaku Organisasi. Terj: Benyamin Molan. New Jersey.Prentice Hall, Inc.

Ruky, Akhmad. (2003) Sumber Daya Manusia Berkualitas. Jakarta; Gramedia Pustaka Utama.

Sekaran, U. (2000) Research methods for business. (3th ed.). New York: Jojn Willey and Sons, Inc.

Sevilla, C. (1993) Pengantar Metode Penelitian. Jakarta: UI Press. 
Simamora, Henry (1999) Manajemen Sumber Daya Manusia. Edisi 2. Yogyakarta: YKPN.

Simamora, Henry. (2004) Manajemen Sumber Daya Manusia, Yogyakarta STIE YKPN.

Steers, R. M., (1977) Antecedents and Outcomes of Organizational Commitment, Administrative Science Quarterly, 22(16), 201-228.

Sudjana. (1986) Metode Statistik (Edisi IV).Bandung:Tarsito.

Sugioko, Sofian. (2009) Pengaruh Variabel Anteseden dan Perantara terhadap Hubungan Komitmen Organisasi dan Kinerja Tugas. Jakarta: Akuntabilitas Maret-2009, 182-188.

Sugiono (2009) Metode Penelitian Bisnis. Bandung: Alfabeta.

Sugiono. (1994) Metode Penelitian Administrasi. Bandung: Alfabeta.
Supranto. J.A. (2004) Analisis Multivariat: Art dan Interpretasi. Ed. Pertama. Cet. Pertama. Gramedia, Jakarta.

Sutrisno, Edy. (2011) Manajemen Sumber Daya Manusia. Jakarta: Kencana Prenada Media Group.

Tulus, Tambunan. (2007) Prospek Koperasi Pengusaha dan Petani di Indonesia dalam Tekanan Globalisasi Ekonomi dan Liberalisasi Perdagangan Dunia. KadinPusat Studi Indutri dan UKM, Jakarta: Universitas Tri-sakti.

Ulrich. D. (1997) Human Resource Champion. Harvard Business School Press. Boston:Massachusett.

Wardani, Anastasia Poppy Kusuma. (2007) Pengaruh Kompetensi Terhadap Kepuasan Kerja Karyawan Pada Rumah Sakit ATMA JAYA Jakarta Divisi Sumber Daya Manusia. (https://lib.atmajaya. ac.id/default.aspx?tabID $=61 \&$ src $=k \& i d=$ 176647) diakses 1 Maret 2015.

Wibowo. (2013) Perilaku dalam Organisasi. Jakarta: Rajawali Pers. 